\title{
Feminist Triumph in Fireless War Against Male Chauvinism in Lessing's “A Woman on a Roof”*
}

\author{
WEI Jian \\ Ningbo Institute of Technology, Zhejiang University, Ningbo, China
}

\begin{abstract}
This paper aims to conduct a detailed thematic analysis of Doris Lessing's short story "A Woman on a Roof" (1963). Through analyzing the chauvinistic responses of the three blue-collar workers toward a stark-naked woman sunbathing herself on the roof, the present author expounds the typical androcentrism prevalent at the time when the story took place. And, by observing how the woman on the roof reacts to the men's despicable remarks and aggressive actions, we see how successful Lessing is in portraying a graceful heroine who effectively launches counterattacks against the men's overbearing aggression and finally wins her victory in the fireless war of feminism against male chauvinism.
\end{abstract}

Keywords: Doris Lessing, feminism, male chauvinism, feminist triumph

\section{Introduction}

Doris Lessing is the Nobel Prize winner of literature in 2007 and an ardent supporter for feminism in many of her works. Her literary breakthrough came in 1962 with the publication of The Golden Notebook, which was regarded as a pioneering work of modern feminism. As far as her literary themes are concerned, she is seen as one of the few writers who have had the courage to uphold the belief in equality between the male and female experience. ${ }^{1}$ In addition to the extraordinary accomplishment of her long novels, she is also universally acknowledged as one of the best short-story English writers of the present era. This paper attempts to conduct a thematic analysis about Lessing's popular short story “A Woman on a Roof” (1963) which uniquely depicts a living image of a daring heroine who has calmly managed to beat back the conventional headstrong masculine attitude of chauvinism toward women, and eventually retains her graceful dignity as an independent new-age woman with admirable feminist qualities. Though there is no actual physical confrontation between the protagonist and her three antagonists, the turbulent clashes between the sulky heroine and her overpowering opponents can be impressively felt like a fireless war between feminism and male chauvinism.

\section{Prevailing Androcentrism in the Mid-twentieth Century Western World}

One may ask what it is that such ordinary male workers should be so aggressively superior to this harmless

\footnotetext{
* This paper is a part of the research project "British Literature: Construction of 100 Core Courses of Ningbo Institute of Technology, Zhejiang Universtity. Serial number: 20700545903.

WEI Jian, associate professor, master, School of Foreign Language Studies, Ningbo Institute of Technology, Zhejiang University.

${ }^{1}$ http://www.jxteacher.com/djg/column53133/94008773-5d74-4246-b070-8b483fdeedbf.html
} 
woman sunbathing on the rooftop. To clearly understand this, we have to look back at the social background when the story was written. Between the 1950s and early 60s prior to the women's liberation movement in the western hemisphere, men enjoyed a far superior social status both financially and politically than did women. Masculine chauvinism was infiltrative and prevailing in every corner of the society. This social superiority consequently gave rise to male mentality to regard women as mere sex objects in the life of men (Henley, 1991). The fact that the three men in Lessing's story have exerted their utmost to render the woman on the roof into a worthless sex object has rightly proved this point. As a result of this male-oriented mentality, aggressive degradation and devaluating comments on women's social and personal significance were seldom seen as out of the ordinary at that time. At every level of the societal life, women were naturally expected to submit to men's demands under any circumstances. Empowered by this widespread stereotype, the three men in the story will naturally be quite assertive about their domineering authority over the sunbathing woman on the roof. In their eyes, a woman should unconditionally give in to any of men's wishful demands whatever social statuses she might possess. In the field of literature, the main task of feminism at the time was to wrestle against the mainstream androcentric prejudices in order to procure the deserved rights for women.

\section{Feminist Triumph of Lessing's New-Age Woman Against Male Chauvinism}

The protagonist of “A Woman on a Roof” enters the plot as a stark-naked woman sunbathing herself on the open roof of a building on a sweltering hot summer day. Lessing deliberately keeps the heroine's name unrevealed throughout the story largely because she wants to convey the notion that a woman's devalued position was extremely common for all females in general. The conflict occurs between this gorgeous sunbathing woman and three blue-collar workers who take notice of her not far away from where they work. The three men are of different years of age: Harry, a socially sophisticated middle-aged family-man with grownup children; Stanley, a handsome, newly-married young man with a cynical attitude to women; Tom, an unsophisticated 17-year-old teenager knowing little about earthly love. Lessing purposely presents the three men with different years of age and varied backgrounds of life to foreshadow the all-level masculine biases toward women. By contrast, the naked sunbathing woman is depicted not in the least scared by the men who have spotted her, nor does she feel ashamed for her bold action. On the contrary, it is the three men who get irritated, astounded, and even furious about this reckless woman's "indecency" on the roof. As is seen in the story, the three men have openly shown overpowering masculine attitudes toward the woman the instant they spot her bathing on the rooftop. Their responses to the woman are as follows respectively.

Harry, the first man, who seems most indifferent to the "immoral" behavior of the woman, debases her physical beauty by considering her presence on the roof rather trivial. He so thinks possibly because he has already experienced his tedious married life for too long and has suffered many an indignity from his wife at home. He cracks a joke about "getting an egg from some woman in the flats under them, to poach it for dinner" (Lessing, 2005, p. 216). This joking comment ironically reveals his headstrong opinion about gender roles: Women are born housewives; instead of going outside they should stay at home to raise children and docilely serve their husbands, let alone shamelessly sunbathe herself stark-naked on the open rooftop at a free will. Therefore, he decidedly expresses his firm assumption, "If she's married, her old man wouldn't like that" (Lessing, 2005, p. 217). 
Stanley, the second man, who is the actual instigator for the other two men, represents the highest level of male chauvinism of the three. He definitely hates being rejected of his domineering manhood by a woman and angrily compares her presence on the rooftop to a crime gotten away with. He sticks to this belief of his so much so that he even thinks that men should possess the right to interfere with any of women's personal affairs in life. He says, "If my wife lay around like that, I'd soon stop her" (Lessing, 2005, p. 217). "I would never let my wife do what she is doing” (Lessing, 2005, p. 217). For him, men should hold all sorts of sway over women's behaviors under any circumstances. Stanley's attitude toward women was extremely popular before and during the women's liberation movement in the West. At that time, women were often contemptuously cast into a disadvantageous social position in the male-dominated society. Naturally, when Stanley discovers that the indifferent sunbathing woman refuses to submit to his self-willed expectation, he scolds her angrily, because she is deviating from the social norm about female behaviors of that time. The second day when he sees the woman sunbathing on the rooftop again, he grows even more outrageous since she acts even more calmly than she did the first day. In answer to his wild catcalls, the woman merely "lifted her head, startled, as if she'd been asleep, and looked straight over at him” (Lessing, 2005, p. 217). Having seen her holding such a cool manner, Stanley now responds with ferocious whistles and outrageous yells. His frustration is now rapidly increasing because she continues sunbathing on the roof in defiance of what men innately think is improper for a woman. Her later action even renders Stanley more emotionally unbearable. While being watched sunbathing on the roof, she merely “looked up at them, cold and remote, then went on reading” (Lessing, 2005, p. 217), as if nothing has ever happened to her - she boldly refuses to take the men into the range of her eyesight. In spite of all this, he still refuses to retreat from this fireless battle. For the third time, Stanley whistles, stomps, yells, and screams ferociously. But the woman remains calm without moving a bit, not even a muscle. Her cool manner toward Stanley seems to have raised her to a more advantageous position. Literary critic Orphia Allen (1990) comments that the negative actions of the workers are due to the fact that the woman is indifferent to their presence as men, and continues sunbathing. Actually, instead of taking any substantial actions in response to their ferocious comments, the sunbathing woman just continues to do whatever she pleases and ignores their harsh comments thrown fiercely at her. But her cool defiance is just too much for the men to bear, because the male chauvinism is inextricably embedded in the depth of their minds. Propelled by the fanatic masculinity, the men's attack against her continues incessantly. Stanley despicably refers her as not like the heroic Lady Godiva, who was the 11th-century noblewoman riding nakedly through the streets of Coventry to save the common people from crippling taxes. The implication of his remark is that this sunbathing woman's action is definitely something pornographic, far from noble or sacred. While talking to Mrs. Pritchett, the blonde wife of an airline pilot, he comments that someone is sunbathing herself on the roof "as if it was a beach up there" (Lessing, 2005, p. 220). He is outraged because the woman is overly asserting her privilege by refusing to sunbathe on the beach as most other people do. In Stanley's eyes, it is unimaginable that the woman should be so shameless and daring as to enjoy such freedom by sunbathing nakedly anywhere she wishes.

The youngest Tom, the third man, probably having not encountered any women's rejection in real life, represents the mildest level of male chauvinism among the three. With a fond passion of fantasy, he wishes to take up the responsibility as a protector to guard the woman against being harassed by the other two men. He heartily imagines that he is not her harasser and that she must have realized his passionate love for her. His dreams of her 
have even convinced himself that meeting this woman is sacredly arranged by fate. Unlike the other two belligerent men, he does not consider her indifference as a hostile rejection. With this fantasy, he even imagines the nearby crane as his heroic aid to rescue her from the two men's agressive molestation. He then dreamily imagines that she has become his lover, fantasizing with his tender emotion how she had once held him in her arms and stroked his hair. So much so that he finally manages to climb up to her space on the rooftop to date her. But, beyond his expectation, she stares angrily at him, saying bluntly "what do you want?" When he tries to make a conversation with her, she promptly brushes him aside, saying, "If you get a kick out of seeing women in bikinis, why don't you take a sixpenny bus ride to Lido? You'd see dozens of them, without all this mountaineering” (Lessing, 2005, p. 221). Expecting to be welcomed by her, he stammers an explanation for his coming here. She allows no idle talk but to order him to go away. Tom gets so dumbfounded and is at such a loss what to do because of a phenomenon called "delay of stupidity" (Fitzgerald, 1986). Eventually, he sheepishly accepts the truth that not every woman is a sex object for men's passion and that masculine mentality cannot produce the desired effect for every woman. The woman's tone of speaking to him is graceful, cool, and dispassionate as if in a peaceful confrontation against her opponent; yet, her brief remarks empowered by potent action are really powerful enough as a dynamic weapon to conquer all men's bigoted chauvinism in this fireless war.

\section{Conclusion}

Feminism is in essence a systematic ideology to liberate women from all sorts of social injustices caused by their devalued gender. Throughout human history, women have suffered too much from the unjust treatment of the mainstream male-oriented society. Even nowadays, most women remain silent about their own destiny. Facing enormous resistance, Doris Lessing effectively uses this new-age rooftop image as her spokesperson to counterattack the prevalent male chauvinism. With the cool weapon of retaliation, the story's heroine has become an envied victor in the fireless battle between feminism and male chauvinism. To a great extent, she is not just a brave sunbathing beauty on a rooftop, but rather, a heroic feminist fighter for women of all ages the world over.

\section{References}

Allen, O. J. (1990). Short story criticism (Vol. 16, p. 199). T. Vottler (Ed.). Detroit, MI: Gale Research.

DiYanni, R., \& Rompf, K. (1995). Book of fiction. New York: McGraw-Hill Inc..

Drabble, M. (2005). The Oxford companion to English literature. Beijing: Foreign Language Teaching and Research Press.

Fitzgerald, E. (1986). Retreat from home. In T. Votteler (Ed.), Short story criticism (p. 186). New York: Gale Research Inc..

Henley, N. (1991). Womanspeak and manspeak. In J. Henslin (Ed.), Down to earth sociology (pp. 149-156). New York: The Free Press.

Kirszner, L. G., \& Mandell, S. R. (2004). Literature reading, reacting, writing (5th ed., pp. 41-57). Beijing: Peking University Press.

Lessing, D. (2005). A woman on a roof. In S. R. WANG (Ed.), Selected readings in British literature (2nd ed., pp. 216-222). Beijing: Higher Education Press.

WEI, J., \& WEN, Z. L. (2013). A guide to appreciating English literature (2nd ed., p. 304). Hangzhou: Zhejiang University Press. 